\title{
A Case of Early Septal Reconstruction with Autogenous Cartilage Graft with Bioaborbable Plate in a 13-Year-Old Male of Nasal Septal Abscess
}

\author{
Jin Yoon, Myeongsin Kang, and Jae-Hoon Lee \\ Department of Otolaryngology-Head and Neck Surgery, Institute of Wonkwang Medical Science, College of Medicine, \\ Wonkwang University, Iksan, Korea
}

\begin{abstract}
비중격 농양이 발생한 13 세 남자에서 자가 연골과 생체흡수성 판을 이용한 조기 비중격 재건술 1 예
윤 진 · 강명신 · 이재훈

원광대학교 의과대학 이비인후과학교실
\end{abstract}

\author{
Received May 29, 2017 \\ Revised July 19, 2017 \\ Accepted August 7, 2017 \\ Address for correspondence \\ Jae-Hoon Lee, MD, PhD \\ Department of Otolaryngology- \\ Head and Neck Surgery, \\ Institute of Wonkwang Medical \\ Science, College of Medicine, \\ Wonkwang University, \\ 895 Muwang-ro, Iksan 54538, Korea \\ Tel $+82-63-850-1441$ \\ Fax $+82-63-841-6556$ \\ E-mail leejaehoon64@gmail.com
}

Nasal septal abscess is a serious condition that necessitates urgent surgical management, and it may lead to saddle nose deformity caused by the loss of cartilaginous support. To date, there is no consensus among clinicians with regard to early versus late surgical management of the saddle nose deformity. For the growing child, reconstructing the septum is essential for the normal development of the nose. We present a case of nasal septal abscess with a nearly total loss of septal cartilage of a 13 -year-old male. His nasal septum was reconstructed immediately with autologous ear cartilage attached to a bioabsorbable plate through open approach. The aesthetic problems such as the saddle nose have not occurred during the follow-up period.

Korean J Otorhinolaryngol-Head Neck Surg 2019;62(2):131-4

Key Words Abscess $\cdot$ Autologous cartilage $\cdot$ Bioabsorbable plate $\cdot$ Reconstruction $\cdot$ Septum.

\section{서 론}

비중격 농양은 비중격 연골부와 연골막 사이에 농양이 고 이는 질환으로 대부분이 외상성 원인이지만, 드물게 비전정 염, 급성 부비동염, 치성 감염 등에 의해 발생될 수 있다. ${ }^{1)}$ 비 중격 농양 발생 시 비중격 연골의 괴사로 인하여 안장코가 발 생될 수 있다. ${ }^{2)}$ 그러므로 비내시경검사에서 비중격 연골부에 국소적인 종창과 파동이 관찰되면 비중격 농양을 의심하고 즉각적으로 절개 배농술을 시행해야 한다. 농양에 의한 허혈성 변화로 인해 비중격 연골이 2 3일 이내에 괴사하기 때문이다.

저자들은 코 외상 후 발생한 비중격 농양으로 인한 거의 대

This is an Open Access article distributed under the terms of the Creative Commons Attribution Non-Commercial License (http://creativecommons.org/licenses/by-nc/4.0) which permits unrestricted non-commercial use, distribution, and reproduction in any medium, provided the original work is properly cited.
부분의 비중격 연골이 괴사된 13 세의 남자 환자에서 비중격 농양 배농 후 자가 귀 연골과 함께 생체흡수성 판을 이용하여 조기 비중격 재건술을 시행한 1 예를 소개하고 문헌 고찰과 함 께 보고하는 바이다.

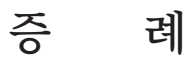

13세 남자 환자가 내원 9일 전에 코를 탁자에 심하게 부딪친 후 발생한 코막힘을 주소로 내원하였다. 환자는 코막힘이 점 점 심해지는 양상이었으나 수상 후 치료는 받지 않았던 상태 였으며, 내원 당시 생체 징후에 이상은 없었다.

내원 당시 혈액검사에서 white blood cell(WBC) $7.8 \times 10^{3} /$ $\mu \mathrm{L}$, erythrocyte sedimentation rate(ESR) $16 \mathrm{~mm} / \mathrm{hr}, \mathrm{C}-$ reactive protein(CRP) $37.4 \mathrm{mg} / \mathrm{L}$ 로 $\mathrm{ESR}$ 과 $\mathrm{CRP}$ 가 증가한 상 
태였다. 비내시경검사에서 양측 비강을 가득 채운 비중격 종 창 소견이 관찰되었다(Fig. 1). 내원 당시 시행한 부비동 전산 화단층촬영에서 비중격 전방 부위에 저음영 병변이 관찰되 었다(Fig. 2).

신체검사와 전산화단층촬영 소견을 종합하여 비중격 농양 의 진단하에 내원 당일 국소 마취하에 절개 배농술을 시행
하였다. 좌측 비중격 미부에 반관통 절개 후 다량의 농성 분 비물이 배출되었으며 채취된 농에 대한 세균배양검사를 시행 하였다. 배농 후 비중격 안을 관찰하였을 때 L형 지주(L-strut) 를 포함한 전체 비중격 연골이 괴사된 상태였으며, 생리식염 수로 비중격 내부를 수차례 세척한 후 배액관 삽입 및 고정 후 Merocel ${ }^{\circledR}$ (Medtronic Inc., Minneapolis, MN, USA)로

Fig. 1. Endonasal examination shows a bilateral swelling in the nasal septum completely obstructing the right (A) and left (B) nasal cavity.
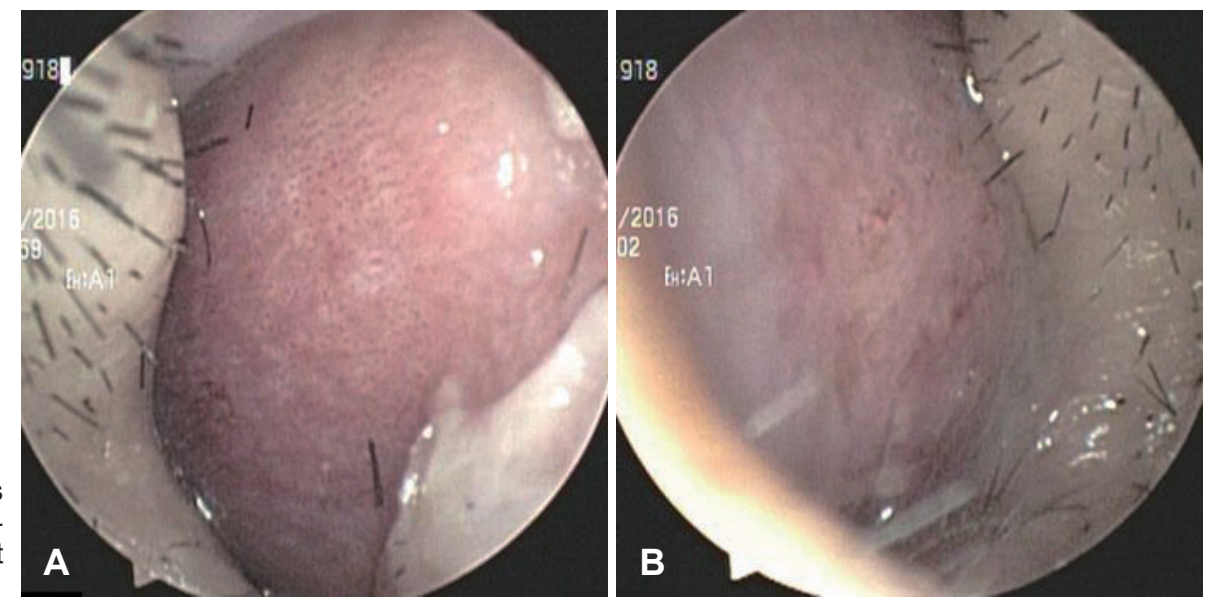

Fig. 2. Axial (A) and coronal (B) images of paranasal computed tomography scan show a low-density lesion on the anterior portion of the nasal septum with resultant bilateral nasal airway obstruction.
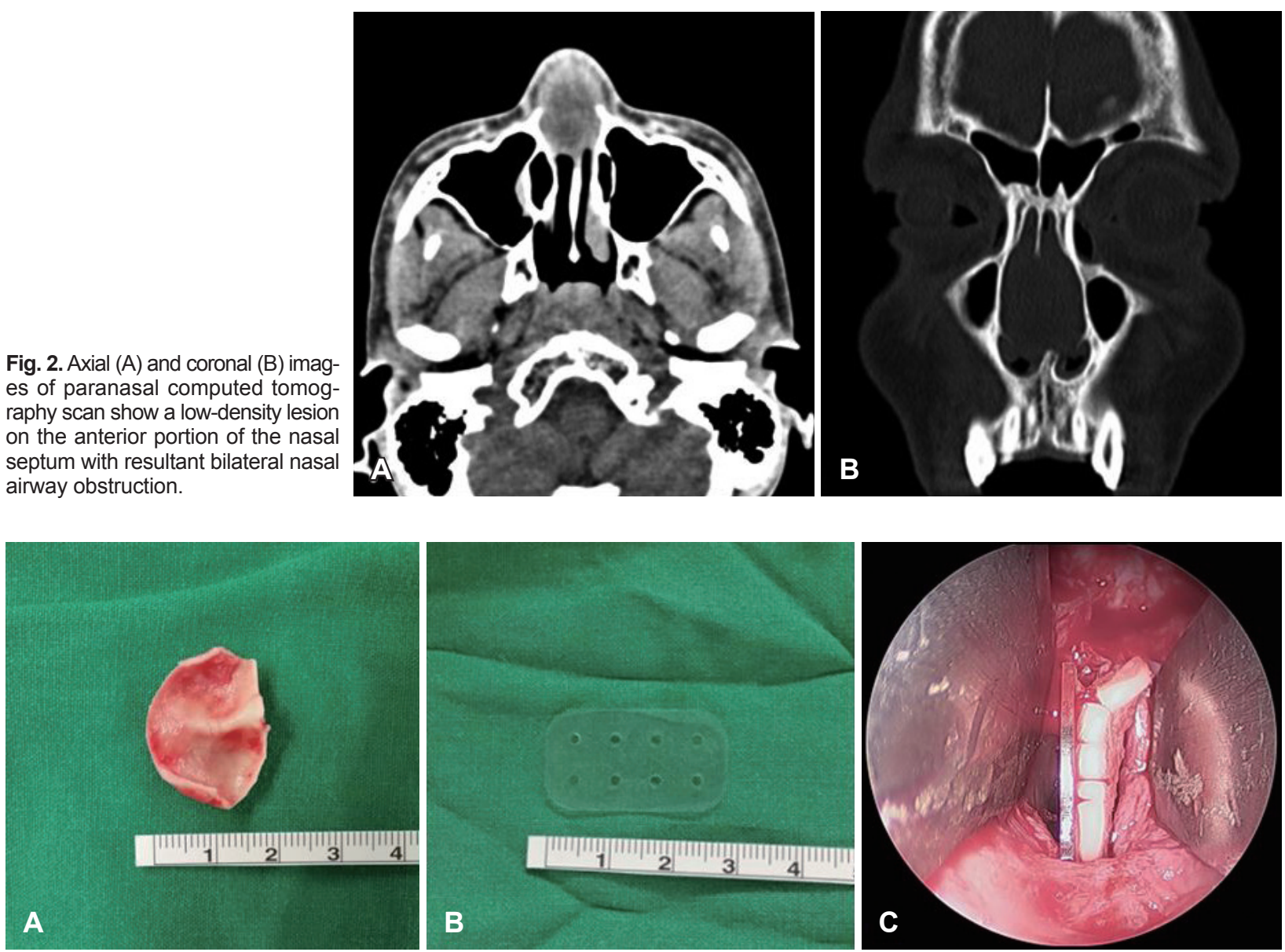

Fig. 3. Early septal reconstruction. Autologous ear cartilage (A). A bioabsorbable plate (B). The autologous ear cartilage with the bioaborbable plate placed along the nasal septum and secured in place (C). 


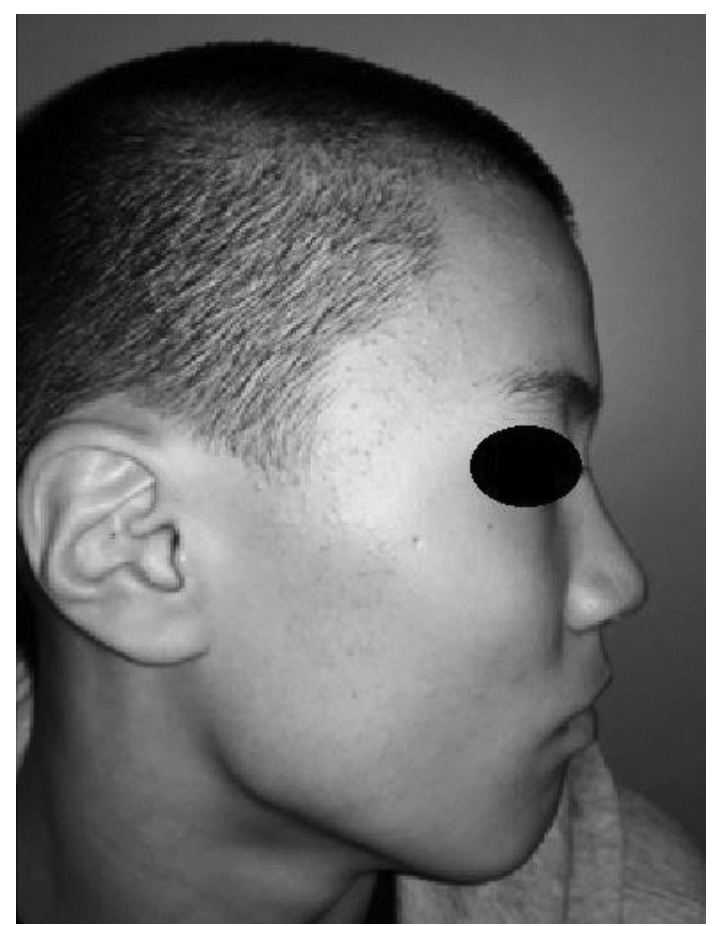

Fig. 4. One year after the septal reconstruction a lateral view shows no aesthetic problems such as the saddle nose.

팩킹하였다.

세균배양검사 결과에서 Staphylococcus aureus 가 동정되었 다. 배농 후 3세대 cephalosporins계인 cefolatam(2회/일, 1회 $2 \mathrm{~g}$ ), clindamycin(3회/일, 1회 $300 \mathrm{mg}$ )을 이용한 항생제 주 사 치료를 하였고, 배농 3 일째 Merocel ${ }^{\circledR}$ 을 제거하였다.

차 후 안장코 발생 가능성이 매우 많아 비중격 재건술을 계 획하였다. 배농 후 5 일째 배액관을 제거하였고 개방적 접근법 을 통해 수술을 진행하였으며 결손된 비중격 연골양은 $1 \mathrm{~mm}$ 실라스틱 판을 템플리트(templete)로 이용한 측정치는 $23 \times$ $14 \mathrm{~mm}$ 였다. 그 다음 우측 귀에서 연골을 채취하였으며 연골 의 오목한 부위에는 교차절개(cross-hatching incision)를 하 였다. 연골과 $0.3 \mathrm{~mm}$ 두께의 구멍이 있는(perforated) 생체흡 수성 판(Fix bone plate; ETRION Co., Cheongju, Korea)은 5-0 polydioxanone(PDS)으로 봉합하였으며 템플리트에 맞 게 자른 후 외측비연골, 사골수직판, 서골, 상악골릉 사이에 주의 깊게 삽입하였다(Fig. 3). 비중격 점막과 연골 및 생체흡 수성 판은 4-0 vicryl로 조심스럽게 고정 봉합(quilting suture) 후, Merocel ${ }^{\circledR}$ 팩킹과 함께 절개 부위 봉합 후 수술을 끝냈다. 비중격 재건술 5 일째 $\mathrm{WBC} 7.6 \times 10^{3} / \mu \mathrm{L}, \mathrm{ESR} 6 \mathrm{~mm} / \mathrm{hr}$, CRP $5.7 \mathrm{mg} / \mathrm{L}$ 의 정상 수치로 회복되었으며, 특이 사항이 관찰되지 않아 재건술 후 7일째 퇴원하였다. 퇴원 후 cefpodoxime(2 회/일, 1회 $100 \mathrm{mg}$ )을 3주 복용하였다. 이식물 삽입 후 비중 격의 염증 소견 및 안장코 발생 여부를 확인하기 위하여 재건
술 후 첫 1 개월은 1 주 간격으로, 그 다음 2 개월은 2 주 간격, 그 다음 3 개월은 한 달 간격으로, 그 후는 3 개월에 1 회씩 정기 적으로 관찰하고 있다. 현재 수술 후 1년이 경과되었으며 안장 코와 같은 비중격 농양의 합병증은 관찰되지 않고 있다(Fig. 4).

\section{고 찰}

비중격 농양 후 발생한 괴사된 비중격 연골에 대한 재건술 의 시기에 대해 명확하게 밝혀져 있지는 않다. ${ }^{3)}$ 일반적으로 재 건술의 시기는 조기 재건술과 지연 재건술로 구분할 수 있는 데, 조기 재건술은 배농절개술과 동시에 혹은 배농절개술 후 며칠 내 시행하는데 안장코와 같은 외비 변형의 방지와 더불 어 특히 성장하는 시기인 소아와 청소년기에 정상적인 코 발 육을 위해 재건술을 일찍 시행하는 방법이다. 지연 재건술은 성인이 될 때까지 기다리는데 조기 재건술이 소아와 청소년기 의 정상적인 코 발달을 보장할 수 없어 차후 재수술이 필요 할 수 있으므로 차라리 성인이 되어서 기능적 및 미용적 코 문 제를 시행하는 방법이다.

소아 및 청소년인 경우 조기 재건술에 대한 설득력이 높 다. ${ }^{4-7)}$ 첫째, 재건술 후 정상적인 코 발달을 기대할 수 있는데 이전 보고 ${ }^{4}$ 에서 연골과 생체흡수성 판을 이용한 조기 비중격 재건술 후 성장에 따른 같은 연령대의 소아와 청소년의 평균 코 길이와 비첨 돌출(nasal tip projection)과의 비교에서 유 의한 차이를 보이지 않았다. 둘째, 안장코와 같은 외비 변형으 로 인해서 청소년기 때 자기 이미지(self-image) 혹은 자긍심 (self-esteem)에 심각한 문제를 초래할 수 있기 때문이다.

비중격 재건술의 접근방법은 비중격 교정술 때 흔히 사용 되는 비강 내 접근방법보다는 개방 접근이 선호되는데 그 이 유로는 결손된 연골양을 측정하기 쉽고 이식물을 삽입하는 데 편리하다는 장점이 있기 때문이다. ${ }^{7)}$ 재건술에 사용되는 재 료로는 감염, 흡수, 그리고 거부 반응이 적은 자가 연골 조직 이 선호된다. 자가 연골 조직으로 늑연골 혹은 귀 연골을 채 취하여 사용할 수 있는데, 귀 연골이 채취하기가 쉬워 선호 되나 휘어져 있는 특성 때문에 편평한 부위를 많이 얻기 쉽지 않다는 단점도 있다. 이런 문제에 대해 본 예에서는 오목한 부위에 교차절개를 하였다.

이식에 사용되는 생체흡수성 판은 비흡수성인 인공 삽입물 (alloplastic material)에 비해 감염 빈도가 훨씬 적어 자가 연 골과 함께 안전한 이식 재료로 알려져 있다. ${ }^{8}$ 비중격 미부의 만곡이 있는 환자를 대상으로 생체흡수성 판 부목 이식을 시 행한 후 평균 9.2개월(4 13개월) 추적 기간 동안 이식에 따른 수술 부위 감염이나 이물질에 대한 거부 반응은 관찰되지 않았다.") 비중격 교정술과 외비성형술을 동시에 시행할 때 L 
형 지주 지지를 위해 생체흡수성 판을 사용하였던 88명 중 1 명(1.1\%)에서 비중격 농양이 발생하였으며 즉, 감염 빈도는 매 우 낮았다. ${ }^{10)}$ 본 예에서는 비중격 농양 배농 후 즉시 비중격 내부를 생리식염수로 수차례 세척하였으며 환자에게 항생제 를 주사하였다. 또한 수술 부위 감염 방지를 위해 조기 비중 격 재건술 동안에 비중격 내부를 항생제가 포함된 생리식염 수로 수차례 세척하였고, 연골과 생체흡수성 판은 항생제 용 액에 10 분 동안 담근 후 비중격 내부에 삽입하였다.

생체흡수성 판으로 PDS와 polylactic-Co-glycolic acid (PLGA)가 사용되는데 수술 당시 국내에서 PDS 판이 유통되 지 않았기 때문에 이번 연구에서는 자가 귀 연골과 함께 사용 한 PLGA를 연골을 고정하는 뼈대(scaffold)로 사용하였다. PLGA의 기계적 강도는 10 주까지 유지되면서 30 개월 이내에 체내에서 완전히 흡수되어 제거할 필요가 없어 두개안면성형 수술에 많이 사용된다. ${ }^{9)}$ 생체흡수성 판은 구멍의 유무에 따 라 구멍이 있는 형태와 구멍이 없는(non-perforated) 형태로 구분될 수 있다. Tweedie 등드는 비중격 재건 시 구멍이 없는 생체흡수성 호일(foil)이 구멍이 있는 생체흡수성 호일을 사용 한 경우에 비해 안장코 발생이 많았다고 보고하였는데, 발생 이유로 구멍이 없는 경우 비중격 점막연골막판으로부터 혈 류공급을 차단받기 때문으로 추정할 수 있다. 본 연구에서는 $0.3 \mathrm{~mm}$ 두께의 구멍이 있는 형태의 생체흡수성 판을 사용하 여 혈류 차단 방지뿐만 아니라 구멍을 통한 연골과 생체흡수 성 판과의 봉합에 용이하였다. 그러나 구멍이 없는 형태인 경 우 16 게이지 주사바늘을 이용하여 여러 군데 구멍을 만들 수 있다.

본 예와 같이 성장기인 연령에서 비중격 농양으로 인한 비 중격 괴사로 인해 조기 비중격 재건을 시행한 경우는 국내뿐 만 아니라 국외 보고도 매우 드물다. Menger 등ㄴ)의 비중격 농 양으로 인해 비중격 연골이 부분적 혹은 전부 괴사된 3 11세 사이의 6명을 대상으로 귀 연골(5명)과 늑연골(1명)과 생체흡 수성 판인 $\mathrm{PDS}$ 를 같이 사용하였다. 추적관찰 기간은 평균 38 개월(10 68개월)이었으며 안장코와 같은 외비 변형은 발생되
지 않았다.

본 증례는 코 외상 후 치료를 받지 않은 채 9일이 경과되어 비중격 농양으로 인한 전체 비중격 연골이 괴사된 경우로 농 양 배농술 후 귀 연골과 함께 생체흡수성 판을 이용한 조기 비중격 재건술을 시행하였다. 이식 후 비중격 부위의 염증, 안 장코 같은 외비의 변형과 같은 주요 합병증이 발생되지 않아 만족스러운 수술 결과를 얻었다. 끝으로, 비중격 농양으로 인 한 비중격 연골이 괴사된 사례의 경우 조기 비중격 재건술에 대한 축적된 경험과 평가가 필요하다.

\section{REFERENCES}

1) Ambrus PS, Eavey RD, Baker AS, Wilson WR, Kelly JH. Management of nasal septal abscess. Laryngoscope 1981;91(4):575-82.

2) Son HR, Mo JH, Chung JY. A case of septal abscess extending to the nasal dorsum. Korean J Otolaryngol-Head Neck Surg 2014;57(2): 116-9.

3) Alshaikh N, Lo S. Nasal septal abscess in children: from diagnosis to management and prevention. Int J Pediatr Otorhinolaryngol 2011; 75(6):737-44.

4) Menger DJ, Tabink IC, Trenité GJ. Nasal septal abscess in children: reconstruction with autologous cartilage grafts on polydioxanone plate. Arch Otolaryngol Head Neck Surg 2008;134(8):842-7.

5) Zankl A, Eberle L, Molinari L, Schinzel A. Growth charts for nose length, nasal protrusion, and philtrum length from birth to 97 years. Am J Med Genet 2002;111(4):388-91.

6) DeRosa J, Smit JR. Septal abscess in a 14-month-old child: diagnosis, management, and discussion of reconstructive options. Int J Pediatr Otorhinolaryngol 2009;4(4):150-4.

7) Dispenza C, Saraniti C, Dispenza F, Caramanna C, Salzano FA. Management of nasal septal abscess in childhood: our experience. Int J Pediatr Otorhinolaryngol 2004;68(11):1417-21.

8) Boenisch M, Nolst Trenité GJ. Reconstruction of the nasal septum using polydioxanone plate. Arch Facial Plast Surg 2010;12(1):4-10.

9) Kang BS, Kim JT, Lee HS, Shin JM. Correction of caudal septal deviation: septal batten graft with a bioabsorbable plate. Korean J Otorhinolaryngol-Head Neck Surg 2016;59(9):680-3.

10) Fuller JC, Levesque PA, Lindsay RW. Polydioxanone plates are safe and effective for L-strut support in functional septorhinoplasty. Laryngoscope. 2017;127(12):2725-30.

11) Tweedie DJ, Lo S, Rowe-Jones JM. Reconstruction of the nasal septum using perforated and unperforated polydioxanone foil. Arch Facial Plast Surg 2010;12(2):106-13. 